\title{
Impact of COVID-19 on Stock Return in Asian Stock Markets
}

\section{Oshini Kumarapperuma}

Faculty of Management, Uva Wellassa University of Sri Lanka oshinikumarapperuma@gmail.com

\section{N.P. Ravindra Deyshappriya*}

Faculty of Management, Uva Wellassa University of Sri Lanka

\section{R.M.M.C. Rajapaksha}

Faculty of Management, Uva Wellassa University of Sri Lanka medanichanchala123@gmail.com

\begin{abstract}
This study focuses on the impact of COVID-19 on the stock market in the Asian region, highlighting the impact on stock returns of 15 Asian stock markets while observing the nexus between COVID-19 confirmed cases and stock return. The analysis is based on daily closing price indices of selected 15 markets during the period of 1st January 2019 and 30th June 2020. The Event Study method was employed to examine the impact of COVID19 on stock returns, by comparing the calculated abnormal return before and after the event day (20th of January 2020) under two evet windows such as $(0,10)$ and $(10,20)$. Fixed Effect Panel Regression Analysis was applied to observe the impact of the number of COVID-19 confirmed cases on stock return in selected stock markets. The analysis reveals that abnormal returns after the event day were negative and therefore it is apparent that the COVID-19 outbreak has drastically affected the stock returns of selected stock markets of the Asian region. Specifically, two event windows indicate that COVID-19 has an immediate negative impact on all selected stock markets while the long-term negative impact has limited only to the emerging and frontier markets. It is observed that COVID19 confirmed cases negatively affect the stock return of all selected stock markets in the Asian region.
\end{abstract}

Keywords: Abnormal Returns, COVID-19, Stock Markets, Stock Returns

*Corresponding Author: ravindra@uwu.ac.lk 


\section{Introduction}

Stock markets are highly sensitive to both external and internal shocks, and in fact, the sensitiveness of stock markets is more substantial with the global emergency announced due to the current COVID-19 outbreak. However, stocks markets are considered as one of the key components of the financial market and the stock markets play a vital role in the economies of respective countries. The stock markets allow investors to earn financial returns by trading stocks while facilitating the financial requirement of the corporate sector. However, stocks markets are considered as one of the key components of the financial market, and the stock markets play a vital role in the economies of respective countries. The stock markets allow investors to earn financial returns by trading stocks while facilitating the financial requirement of the corporate sector. Globalization has steadily increased the capital flows across the borders expanding the role of the stock markets. Asian stock markets have been rapidly growing over time compared to the stocks markets in other regions. Currently, more than half of the listed companies in the world are from the Asian region. Moreover, Asian companies accounted for $51 \%$ out of all initial capital earned by offering Initial Public Offerings (IPOs) in 2018. The increased intervention of public equity financing by Asian companies leads to expand the role of Asian stock markets in global equity financing. As figure 01 illustrates, the share of capital owned by Asian markets has sharply increased during the last two decades. Specifically, capital owned by Asian markets has increased from 19\% (2000-2002) to 42\% by 2016-2018 while the capital raised by Europe and United States markets has considerably declined (Figure 1).

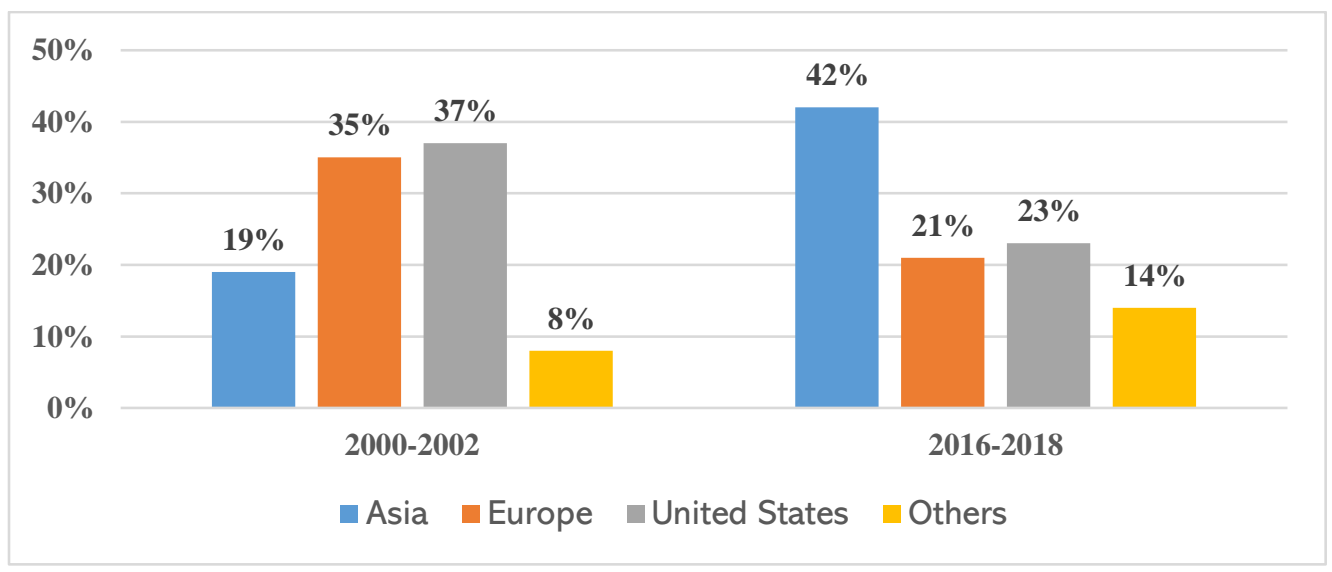

Figure 1: Shares of Asian Markets in Global Public Equity Financing Source: OECD Equity Market Review ASIA, 2019

Moreover, the global role of Asian markets is more substantial when considering the number of IPOs. Asia accounted for 11 out of the top 20 markets in terms of global nonfinancial IPOs during the last decade and China was the largest market with the highest 
number of listings, even going beyond the listing of United States. Similarly, markets in Hong Kong, India, Korea, and Japan reported as $3^{\text {rd }}, 5^{\text {th }}, 6^{\text {th }}$ and $7^{\text {th }}$ places showing the importance of Asian markets among the global players. Similar to the stock exchange in the United States and Europe, most of the stock exchange in Asian economies have also experienced important changes in terms of ownership, legal, and manner of listing. Some stock exchange groups have been created due to collaboration between stock exchanges while some other traditional stock exchanges have been acquired by another stock exchange. Specifically, the Tokyo Stock Exchange Group and Osaka Securities Exchange jointly established the Japan Exchange Group (JPX) in 2013.

Apart from that, Table 1 indicates some key indicators related to selected Asian markets. According to Table 1, Tokyo Stock Exchange in Japan accounts for the highest market capitalization (5297 USD Billion) and the highest number of listed companies (3657). Similarly, Tokyo Stock Exchange owns the highest trading volume that is worth 6291 USD Billion. Shanghai Stock Exchange in China, Stock Exchange of Hong Kong, and National Stock Exchange in India recorded the second, third, and fourth highest market capitalization respectively. Hence, 5 (Japan, China, Hong Kong, India and Korea) out of the top 10 stock markets in terms of market capitalization are located in Asia. However, the highest turnover in Asian markets accounted for by Shanghai Stock Exchange in China (2.14) followed by Korea Stock Exchange (1.77).

Despite the Asian markets having been performing well during the last decade, the recent pandemic situation which emerged in China drastically affect the smooth running not only of the Asian market but at the global level also. COVID-19 was firstly observed in Wuhan, China in late 2019, and however, it spread across the globe and therefore the World Health Organization (WHO) announced a global emergency by early 2020. In addition to the devastating health impacts of COVID-19, it has resulted in pathetic economic and social impacts as well. During the initial period of the outbreak, countries imposed domestic and international travel restrictions along with some other precautionary measures without paying much attention to the long-term social and economic impacts.

According to the historical data related to the pandemic situation SARS in 2003 destroyed USD, 50 Billion (Raga, 2020) of the World's output, and the Asian Development Bank has now estimated that global output may drop from USD 77 Billion to USD 347 Billion or by $0.1 \%$ to $0.4 \%$ of global GDP (ADB, 2020). No doubt that China is the most adversely affected economy approximately accounting for two-thirds of the global GDP drop-down and the rest impact on the global economy is shared by both developing Asia and the rest of the world equally. Impact on China's economy is more substantial through their stock markets, paused production and cancelled flights, and international travels. Currently, China is the second-largest economy in the world and therefore China's slowdown will adversely affect other countries as well and collapsing down of economies is clearly reflected through their stock markets. In fact, most of the stock markets in the Asian region are highly affected by COVID-19, and while some stock exchanges have already been closed. 
Table 1: Key indicators of the Stock Exchanges in the Asia Region (As of the end of 2018)

\begin{tabular}{|c|c|c|c|c|c|c|c|c|c|}
\hline Country & $\begin{array}{l}\text { Stock } \\
\text { exchange }\end{array}$ & Legal Status & $\begin{array}{l}\text { Self- } \\
\text { listing }\end{array}$ & $\begin{array}{l}\text { Market } \\
\text { capitalization } \\
\text { (USD billion) }\end{array}$ & $\begin{array}{l}\text { Market } \\
\text { capitalization } \\
\text { /GDP }\end{array}$ & $\begin{array}{l}\text { Number of } \\
\text { listed } \\
\text { companies }\end{array}$ & $\begin{array}{l}\text { Trading } \\
\text { volume } \\
\text { (USD } \\
\text { billion) }\end{array}$ & $\begin{array}{l}\text { Total } \\
\text { value } \\
\text { traded } \\
\text { / GDP }\end{array}$ & Turnover \\
\hline Hong Kong & $\begin{array}{c}\text { SE of Hong } \\
\text { Kong }\end{array}$ & $\begin{array}{l}\text { Joint Stock } \\
\text { Company }\end{array}$ & Yes & 3819 & 10.52 & 2315 & 2340 & 6.45 & 0.61 \\
\hline Japan & Tokyo SE & $\begin{array}{l}\text { Joint Stock } \\
\text { Company }\end{array}$ & Yes & 5297 & 1.07 & 3657 & 6291 & 1.27 & 1.19 \\
\hline Singapore & $\begin{array}{l}\text { Singapore } \\
\text { Exchange }\end{array}$ & $\begin{array}{l}\text { Joint Stock } \\
\text { Company }\end{array}$ & Yes & 687 & 1.90 & 741 & 222 & 0.61 & 0.32 \\
\hline China & $\begin{array}{c}\text { Shanghai } \\
\text { SE }\end{array}$ & State-owned & No & 3919 & 0.47 & 1450 & 6037 & 1.01 & 2.14 \\
\hline India & National SE & $\begin{array}{c}\text { Joint Stock } \\
\text { Company }\end{array}$ & No & 2056 & 1.53 & 1923 & 1164 & 0.47 & 0.31 \\
\hline Indonesia & $\begin{array}{l}\text { Indonesia } \\
\text { SE }\end{array}$ & $\begin{array}{l}\text { Private } \\
\text { company }\end{array}$ & No & 487 & 0.48 & 619 & 106 & 0.10 & 0.22 \\
\hline Korea & $\begin{array}{c}\text { Korea } \\
\text { Exchange }\end{array}$ & $\begin{array}{l}\text { Joint Stock } \\
\text { Company }\end{array}$ & No & 1414 & 0.87 & 2207 & 2508 & 1.55 & 1.77 \\
\hline Malaysia & $\begin{array}{c}\text { Bursa } \\
\text { Malaysia }\end{array}$ & $\begin{array}{l}\text { Joint Stock } \\
\text { Company }\end{array}$ & Yes & 398 & 1.12 & 912 & 137 & 0.39 & 0.34 \\
\hline Pakistan & Pakistan SE & $\begin{array}{l}\text { Private } \\
\text { company }\end{array}$ & Yes & 71 & 0.23 & 558 & 17 & 0.05 & 0.24 \\
\hline Philippines & $\begin{array}{l}\text { Philippine } \\
\text { SE }\end{array}$ & $\begin{array}{l}\text { Joint Stock } \\
\text { Company }\end{array}$ & Yes & 258 & 0.78 & 267 & 29 & 0.09 & 0.11 \\
\hline Taiwan & Taiwan SE & State-owned & No & 959 & 1.78 & 954 & 967 & 2.10 & 1.18 \\
\hline Thailand & $\begin{array}{l}\text { SE of } \\
\text { Thailand }\end{array}$ & State-owned & No & 501 & 1.03 & 704 & 388 & 0.80 & 0.77 \\
\hline Bangladesh & Dhaka SE & $\begin{array}{l}\text { Private } \\
\text { company }\end{array}$ & No & 40 & 0.14 & 311 & 16 & 0.06 & 0.43 \\
\hline Sri Lanka & Colombo SE & State-owned & No & 16 & 0.18 & 297 & 1 & 0.01 & 0.04 \\
\hline Vietnam & $\begin{array}{c}\text { Ho Chi } \\
\text { Minh SE }\end{array}$ & State-owned & No & 124 & 0.55 & 373 & 46 & 0.22 & 0.40 \\
\hline
\end{tabular}

Source: World Federation of Exchanges, Stock Exchanges' Websites, and IMF World Economic Outlook Database (2018) 
South Asian Journal of Business Insights

The majority of empirical studies have focused on the health impact of COVID -19 and also economic impacts in general. Especially, the unavailability of time series data for a long period of time has discouraged conventional time series analysis related to the impact of COVID-19 on stock returns. Therefore, the current attempts to fill the existing gap by examining the impacts of COVID-19 on stock markets in 15 selected Asian countries. The significance of the current study is the application of the event study method which allows recognizing the impact of a particular event even under a fewer observations. Moreover, unlike country-level studies, the current study has focused on all developed, emerging and frontier markets are therefore the contribution of the present study is timely important. More specifically the study aims to accomplish the following objectives.

1. To examine the impact of COVID-19 on stock returns of the selected stock markets in the Asian region.

2. To observe the relationship between confirmed COVID-19 cases and stock return of the selected stock markets in the Asian region.

The next sections of the paper focus on the literature review followed by the methodology applied for the study. After that, the results of the study are discussed while the final section of the paper has been allocated for conclusion and recommendation followed by a list of references.

\section{Literature Review}

\section{Economic Impact of Pandemic Situation on Economies of Asian Countries}

The economy is a major component of any society which can be identified as a system according to which the money, industry, or trade of a country or a region are organized. In the existing literature, many scholars investigated the association between epidemics and economic developments. Bloom and Mahal (1997) investigated the relationship between AIDS and economic growth and could identify a relationship between those two variables as AIDS is an epidemic that can affect the country's economy by reducing the availability of human capital. Similarly, Barnett et al. (2000) analysed the relationship between AIDS and GDP and observed a negative relationship between AIDS and GDP.

In the period of 2003-2004, Acute Respiratory Syndrome (SARS) could potentially impact the global economy. The impact of the SARS epidemic on human society everywhere around the world was severe (Lee \& McKibbin, 2004). Siu \& Wang (2004) identified the spread of Hong Kong's SARS epidemic, and its economic impact, and concluded that the most severe negative consequences were seen on the customer side, with the short term serious influence by local consumption and the export of tourism and air travel-related services. Chen et al. (2007) studied the impact of the SARS outbreak on hotel stocks' performance in the Chinese mainland and Taiwan stock exchanges and found a significant negative effect. Due to the SARS outbreak, the Taiwanese economy weakened and experienced steep declines in earnings and stock prices. (James et al., 2006). 
Oshini Kumarapperuma, Ravindra Deyshappriya and Rajapaksha

The financial cost of another devastating outbreak of the foot-and-mouth disease as an epidemic that occurred in pigs in Taiwan. Wang et al. (2013) were estimated at US\$ 378.6 million. It included indemnities, vaccines, carcass disposal, environmental protection, miscellaneous expenses, and market value loss. Moreover, Carpenter et al. (2011) analysed the impact of the disease outbreak on economic growth which obtained the pieces evidence that epidemic affected the city the economy.

In Kerala, India, Vijayakumar et al. (2013) examined the relationship between the Chikungunya epidemic emerging in India and the per-capita monthly income. It resulted that there was no relationship between these two variables. In the recent literature, it was highly emphasized the impact of COVID-19 on the economies of the countries. McKibbin and Fernando (2020) found that the GDP losses from the baselines could be higher as $8.4 \%$ for the United States and $6.2 \%$ for China in specific scenarios, and the GDP losses could be up to $5.9 \%$ for the rest of the world. Because the COVID-19 spread despite proceeds and the numbers of death cases and infections are rising, the fate of health and economic problems remains questionable.

In the meantime, Jin et al. (2020) pointed out that SMEs that play a significant role in China, have been severely affected due to a decline in social consumption and rigid expenditure on rents, wages, and interests. Okorie \& Lin, (2020) investigated the significant short-lived contagion effect of the COVID-19 pandemic on the stock markets and observed that stock market returns affected and there is higher volatility during COVID-19 period. Moreover, Zhang et al. (2020) highlighted that uncertainty and economic losses of COVID-19 cause stock markets to become more volatile and unpredictable. Ru et al. (2020) compared the stock market reactions to SARS and COVID19 in 65 countries. They could visualize significant adverse reactions to the two diseases, with SARS experiences tended to react more and a lot before COVID-19.

\section{Impact of Global Crisis on Stock Market Performance in Asian Markets}

One of the crucial players in the economic system which accumulate funds is the stock market. Economists believe that a more prominent increment in stock prices means to reflect future economic growth. Stock market performance is a significant indicator of the stock market. Considering the world money-related framework's condition, it is getting increasingly convoluted; it is critical to discover what variables impact stock market performance changes in isolated nations. Forbes and Rigobon (2001) examined stock exchange co-movements and analysed the different theoretical models of how linkages between countries were calculated. Such factual measures include the probability of a speculative attack, correlation in the asset returns, and the transmission of shocks or volatility. They also clarified what disease is and create models on the most proficient method to decipher spread components. They also recommended that the standard tests inspect cross-market correlations in stock market returns are biased.

A particular study has proposed an understanding of stock markets integrated during periods of financial stability. Aggarwal and Inclan (1999) studied the events that have an 
South Asian Journal of Business Insights

enormous impact on emerging stock market volatility. Results of that study showed that the periods of more tremendous volatility shifts were integrated with country-specific political, economic, and social events such as the Mexican Crisis and the Marcos-Aquino conflict in the Philippines. When considering the spread of the U.S. financial crisis to BRIC countries, Bianconi et al. (2013) used vector autoregressions, simple unconditional volatility measures, co-integration, and conditional volatility, and correlations amongst stock and bond market returns. In the short term period on the U.S. financial stress, BRIC bond markets reacted positively. However, India's bond market was more detached from the other bond markets in BRIC. It was responded less to the U.S. financial stress quantitatively.

The U.S. subprime crisis's transmission onto BRIC countries and examined the financial crisis's impact on the industrial and financial sectors' stock markets and equity markets (Nikkinen et al., 2013). This study identified the degree of contagion by examining BRIC equity markets' industrial and financial sectors. Results show that there is evidence of disease between the U.S. and BRIC markets because of direct linkages both as far as returns and volatility and that Russia and India's equity returns, as well as financial related and industrial sector, returns were affected by U.S. equity market movements preceding to the financial crisis. Chene et al. (2018) found that the SARS epidemic has weakened China's long-term relationship with the four Asian markets. It supported the existence of a time-varying co-integration relationship in aggregate stock price indices. Hence, the SARS outbreak's cost reported in losses higher as in the financial crisis of Asia. It could be estimated at \$3 trillion in GDP and \$2 trillion in financial market equity (Delisle, 2003). Stock market investors may feel pessimistic about the investment prospects in a particular market, selling off that market's stocks under a communicable disease outbreak (Baker et al., 2012). The performance of the stock market positively influences the sentiment of investors. When the stock market performance is trending upwards, investors behave more optimistically because it has less perceived risk. When the stock market performance is trending downwards, investors act as relatively pessimistic.

The stock market return is the central concept that is considered when investors invest in any stock exchange. The stock market return indicates the profit that is generated for investors. Perhaps it generated extra money from the investments. Similarly, it can occur loss from investment. According to the study of Chen et al., (2007), SARS outbreak harmed Taiwan's hotel stock performance. Ali and Afzal (2014) examined the global financial crisis that started in the United States. The study showed that the global financial crisis made a mild negative impact on stock returns and enhanced volatility in Pakistan and Indian stock exchanges. Still, this impact is more substantial on the Indian stock market.

The most dramatic stock market crash was caused by the COVID-19 outbreak (Mazur et al., 2020). According to the Al-Awadhi et al., (2020), during the COVID-19 pandemic, Hang Seng Index and Shanghai Stock Exchange Composite Index were negatively interacted with returns of the infectious disease outbreak in China. Chia et al., (2020) indicated that the movement control order has a significant positive impact on the returns on indices, while overseas financial risks have a negative impact on Malaysian stock 
Oshini Kumarapperuma, Ravindra Deyshappriya and Rajapaksha

returns. Similarly, Lee et al., (2020) investigated the impact of higher numbers of COVID19 cases and observed that higher numbers of COVID-19 cases adversely affect the performance of the Kuala Lumpur Composite index and all sectorial indices with the exception of the Malaysian Real Estate Investment Fund index.

In fact, the most dramatic stock market crash was caused by the COVID-19 outbreak (Mazur et al., 2020). According to the Al-Awadhi et al., (2020), during the COVID-19 pandemic, Hang Seng Index and Shanghai Stock Exchange Composite Index were negatively interacted with returns of the infectious disease outbreak in China. Chia et al., (2020) indicated that the movement control order has a significant positive impact on the returns on indices, while overseas financial risks have a negative impact on Malaysian stock returns. Similarly, Lee et al., (2020) investigated the impact of higher numbers of COVID19 cases and observed that higher numbers of COVID-19 cases adversely affect the performance of the Kuala Lumpur Composite index and all sectorial indices except for the Malaysian Real Estate Investment Fund index.

Al-Awadhi et al., (2020) further elaborated that the daily increase in the total number of confirmed cases and in the total number of deaths in China caused by COVID-19 has a negative and significant impact on the stock returns of all companies. In contrast, Chia et al., (2020) evaluated the negative insignificant impact of daily new confirmed COVID-19 cases and deaths on indices in Malaysia. The stock markets of less-free countries have been affected by the same magnitude of the increase in the number of COVID-19 cases (Erdem, 2020). In particular, the epidemic has the greatest impact on emerging markets in Asia, while it has the lowest impact on emerging markets in Europe (Topcu \& Gulal, 2020).

According to the above-discussed literature, the impact of global crises and other pandemics on stock market performance and stock market returns could be identified. More specifically, the impact of the recent COVID-19 pandemic on Asian stock markets has not been adequately addressed in the literature. Hence, the current study aims to fill the existing gap by examining the impact of COVID-19 on stock markets in the Asian region.

\section{Methodology}

\section{Event Study Method}

The event study method has been historically used by scholars such as Dolley (1933) and Ball and Brown (1968). The event study method has been used in economics and finance disciplines in order to assess the impact of a specific event on particular variables. Particularly, the event study method has been used in stock market analysis, as the effect of a specific event on the stock market is reflected in the stock prices and returns. Studies by Gaver and Battistel (1992), Thompson (1993), Agrawal and Kamakura (1995) have 
South Asian Journal of Business Insights

used the event study method and most of the studies have examined the impacts of various events on Abnormal Returns (ARs) and Cumulative Abnormal Returns (CARs).

\section{Data and Variables}

The study is mainly based on 15 Asian stock markets as indicated in Table 2 and these 15 markets represent developed, emerging and frontier markets in the Asian region. Moreover, Table 2 indicates the major stock indices of each stock market considered for the study.

Table 2: Stock Exchanges and Major Stock Indices of the Selected Asian Market

\begin{tabular}{|c|c|c|c|}
\hline Country & $\begin{array}{l}\text { Country } \\
\text { Classification }\end{array}$ & Stock Exchange & Major Stock Indices \\
\hline Hong Kong & Developed & SE of Hong Kong & HangSeng Index \\
\hline Japan & Developed & Tokyo SE & Nikkei 225 Index \\
\hline Singapore & Developed & $\begin{array}{l}\text { Singapore } \\
\text { Exchange }\end{array}$ & Straits Time Index \\
\hline China & Emerging & Shanghai SE & Shanghai Composite Index \\
\hline India & Emerging & National SE & $\begin{array}{l}\text { National Stock Exchange } \\
\text { (NIFTY) } 50 \text { Index }\end{array}$ \\
\hline Indonesia & Emerging & Indonesia SE & Jakarta Composite Index \\
\hline Korea & Emerging & Korea Exchange & $\begin{array}{c}\text { Korea Composite Stock } \\
\text { Price Index }\end{array}$ \\
\hline Malaysia & Emerging & Bursa Malaysia & $\begin{array}{l}\text { FTSE Bursa Malaysia Kuala } \\
\text { Lumpur Composite (KLCl) } \\
\text { Index }\end{array}$ \\
\hline Pakistan & Emerging & Pakistan SE & Karachi 100 Index (KSE) \\
\hline Philippines & Emerging & Philippine SE & $\begin{array}{c}\text { Philippines Stock Exchange } \\
\text { PSEi Index }\end{array}$ \\
\hline Taiwan & Emerging & Taiwan SE & $\begin{array}{c}\text { Taipei(TPE), Taiwan Stock } \\
\text { Exchange (TAIEX) Index }\end{array}$ \\
\hline Thailand & Emerging & SE of Thailand & $\begin{array}{l}\text { Stock Exchange of Thailand } \\
\text { (SET) } 50 \text { Index }\end{array}$ \\
\hline Bangladesh & Frontier & Dhaka SE & $\begin{array}{l}\text { Bangladesh Dhaka Stock } \\
\text { Exchange Broad Index }\end{array}$ \\
\hline Sri Lanka & Frontier & Colombo SE & $\begin{array}{c}\text { Colombo Stock Exchange } \\
\text { All Share Index }\end{array}$ \\
\hline Vietnam & Frontier & Ho Chi Minh SE & $\begin{array}{l}\text { Vietnam Ho Chi Minh Stock } \\
\text { Index }\end{array}$ \\
\hline
\end{tabular}

Source: Created by authors based on Global Market Accessibility Review Report - 2020 of Morgan Stanley Capital International (MSCl).

The daily closing stock prices of the three most active companies (See Annex 01) were collected over the period of 01st January 2019, and ends Tuesday, 30th June 2020 in order to calculate the stock return for each company. In addition to stock price, other 
relevant variables such as market capitalization were also collected from the website of inwestin.com. (WWW. Investing.com) Apart from that, a number of COVID-19 confirmed cases were collected from World Health Organization (WHO).

\section{Event Study Set-up and Data Analysis}

Setting up of event study first requires recognizing the event day. Despite COVID-19 emerging in Wuhan - China in December 2019, it has not been announced as a transmittable virus among people till the $20^{\text {th }}$ of January 2020 . Hence, after the $20^{\text {th }}$ of January 2020, COVID-19 attracted global public attention through the huge publicity given by global Media. Hence, the $20^{\text {th }}$ of January 2020 was considered as the event day of this study. Two event windows $(0,10)$ and $(10,20)$ were assigned to examine the impact of COVID-19 on stock returns. Two event windows were also considered for Pre-COVID and COVID periods and therefore $(0,10)$ window observes both 10 days before and after the event day while $(10,20)$ window examines the impacts during $10-20$ days before and after the event day.

Since the study examined the impact of COVID-19 on ARs, it is required to calculate the ARs using the stock returns of the Asian market. Actual return can be calculated through the following regression model.

$$
R_{i, t}=\alpha_{i}+\beta_{j} R_{m t}+\varepsilon_{i, t}
$$

After calculating the $\widehat{\alpha}_{\mathrm{i}}$ and $\hat{\beta}_{\mathrm{i}}$ coefficient of equation (1), the expected return and abnormal return were calculated using equations (2) and (3) respectively.

$$
E\left(R_{i, t}\right)=\hat{\alpha}_{i}+\hat{\beta}_{j} R_{m t}+\varepsilon_{i, t}
$$

$$
A R_{i, t}=R_{i, t}-E\left(R_{i, t}\right)
$$

Where;

$\mathrm{R}_{\mathrm{i}, \mathrm{t}}$ - The actual return of index $\mathrm{i}$

$E\left(R_{i, t}\right)$ - Expected return

$A R_{i, t}-$ Abnormal return

After that, calculated abnormal returns were compared across pre-COVID and COVID periods considering two event windows, to examine whether there is a significant difference in abnormal return in Asian countries before and during the COVID-19 outbreak. 
South Asian Journal of Business Insights

Align with the second objective of the study, the fixed effect panel regression model indicated in equation (4) is estimated to examine the impact of confirmed COVID-19 cases on abnormal stock return. Moreover, the panel analysis has been controlled for both time and country factors and the models were estimated under robust standard errors to deal with the heterogeneity problem which is common in economic data.

$$
A R_{i t}=\propto+\beta_{1} \log _{\text {Case }_{i t}}+\beta_{2} \text { Return }_{i t}+\beta_{3} E_{\text {Rate }_{i t}}+\beta_{3} M_{\text {Capital }_{i t}}+\gamma_{i}+\delta_{t}+
$$

Where:

$$
\begin{aligned}
& A R_{i t} \text { - Abnormal Return of Stock Exchange } \mathrm{i} \text { at time } \mathrm{t} \\
& \propto \text { - Intercept }(\mathrm{i}=1,2,3,4 \ldots \ldots \mathrm{n}) \\
& \beta \mathrm{i}-\text { Coefficient for the Explanatory Variables } \\
& \text { Log }_{\text {Case }_{i t}} \text { - Log of Confirmed Cases } \\
& \text { Returnit - Return } \\
& \text { ERateit - Exchange Rate } \\
& M C a p i t a l i t-\text { Market Capitalisation } \\
& \gamma i-\text { Country Control } \\
& \delta t \text { - Time Control } \\
& \varepsilon_{i t}-\text { Error Term }
\end{aligned}
$$

\section{Results and Discussion}

\section{Descriptive Statistics on Stock Indices of Sample Countries}

Table 03 indicates the mean and standard deviations of the stock returns of Asian Stock Markets before and after the event day $\left(20^{\text {th }}\right.$ of January 2020$)$. The period before the event day considered the data from $1^{\text {st }}$ of January 2019 to $19^{\text {th }}$ of January 2020. Conversely, the period after the event day includes the data from $21^{\text {st }}$ of January 2020 to $30^{\text {th }}$ of June 2020. According to Table 3, before the event day, only three countries (Hong Kong, Malaysia, and Thailand) has reported negative stock returns while all other countries have reported positive stock returns. In contrast, stock returns of 12 countries out of 15 selected countries have sharply declined and reported negative values after the event day. Therefore, the stock returns of most Asian Stock Markets have been dramatically affected by the outbreak of COVID-19. Apart from that, standard deviation represents the volatility of stock returns. Table 03 also compares the standard deviation of the stock returns of the selected 15 Asian Stock Markets during the periods before and after the event day. In fact, standard deviations of stock returns of all the markets have considerably increased 
Oshini Kumarapperuma, Ravindra Deyshappriya and Rajapaksha

after the event day. A closer inspection reveals that the increment of the standard deviation of stock returns is approximately $10 \%$ compared to before the event day. Hence, the COVID-19 outbreak has caused not only reducing the stock return but also increasing the volatility in the stock market.

Table 3: Descriptive Statistics of Asian Region Stock Markets

\begin{tabular}{lcccc}
\hline Country & \multicolumn{2}{c}{ Before Event Day } & \multicolumn{2}{c}{ After Event Day } \\
\cline { 2 - 5 } & Mean & Std. Deviation & Mean & $\begin{array}{c}\text { Std. } \\
\text { Deviation }\end{array}$ \\
\hline Hong Kong & -0.0012 & 0.014509 & 0.004422 & 0.073622 \\
Japan & 0.001942 & 0.023694 & -0.01892 & 0.312207 \\
Singapore & 0.001187 & 0.019263 & -0.00712 & 0.107922 \\
China & 0.001549 & 0.0255 & -0.00412 & 0.062397 \\
India & 0.004981 & 0.036452 & -0.02134 & 0.345818 \\
Indonesia & 0.001279 & 0.020866 & -0.01504 & 0.292764 \\
Korea & 0.00 & 0.060982 & 0.00 & 0.455779 \\
Pakistan & 0.002838 & 0.036089 & -0.00982 & 0.176261 \\
Malaysia & -0.0105 & 0.034573 & -0.00578 & 0.105337 \\
Philippines & 0.002114 & 0.033365 & -0.01373 & 0.219922 \\
Taiwan & $5.40484 \mathrm{E}-05$ & 0.016702 & -0.01026 & 0.146978 \\
Thailand & -0.00478 & 0.042459 & 0.002282 & 0.043942 \\
Bangladesh & 0.0008 & 0.014753 & -0.00766 & 0.135403 \\
Sri Lanka & 0.006797 & 0.057072 & -0.00631 & 0.56420 \\
Vietnam & 0.00 & 0.042165 & -0.03 & 0.503183 \\
\hline
\end{tabular}

Source: Authors calculation based on collected data

\section{Comparing Abnormal Return on Event Day and One Day After}

This section attempts to observe the behaviour of ARs of the selected countries right after one day, before formally examining the impact of COVID-19 through event windows. Table 4 compares the ARs of the event day $\left(20^{\text {th }}\right.$ of January 2020$)$ of the selected stock markets with the ARs after one day of the event day ( $21^{\text {st }}$ of January 2020$)$.

ARs of the event day indicates that countries such as Hong Kong, Pakistan, Malaysia, Taiwan, and Bangladesh have rapidly reacted to the information flowing about the spread of COVID-19 and therefore have reported negative abnormal return even in the event day. In contrast, the abnormal return of Japan, Singapore, China, India, Indonesia, Korea, the Philippines, Thailand, Sri Lanka, and Vietnam were positive on the event day. However, abnormal returns of all selected countries except counties such as Indonesia, Korea, Thailand, Sri Lanka, and Vietnam were negative one day after the event day. In fact, on the event day and one day after the event day, the countries' stock markets reacted when the 
South Asian Journal of Business Insights

news on the COVID-19 was widely and firstly reported in the international media and accordingly stock indices have started collapsing.

Table 4: Abnormal Return on Event Day and One Day After

\begin{tabular}{lcc}
\hline Country & \multicolumn{2}{c}{ Abnormal Return } \\
\cline { 2 - 3 } & Event Day & One Day After \\
\hline Hong Kong & -0.0155 & -0.0032 \\
Japan & 0.0013 & -0.0092 \\
Singapore & 0.0015 & -0.0060 \\
China & 0.0019 & -0.0059 \\
India & 0.0011 & -0.0001 \\
Indonesia & 0.0273 & 0.0001 \\
Korea & 0.0082 & 0.0140 \\
Pakistan & -0.0129 & -0.0132 \\
Malaysia & -0.0096 & -0.0282 \\
Philippines & 0.0050 & -0.0068 \\
Taiwan & -0.0041 & -0.0004 \\
Thailand & 0.0135 & 0.0062 \\
Bangladesh & -0.0123 & -0.0187 \\
Sri Lanka & 0.0054 & 0.0064 \\
Vietnam & 0.0012 & 0.0053 \\
\hline
\end{tabular}

Source: Authors calculation based on collected data

Cumulative Abnormal Return in the Event Window $(0,10)$ and $(10,20)$

Event window $(0,10)$ can be used to indicate the impact of COVID-19 on ARs of ten days before and after the event day. Table 05 compares the Cumulative Abnormal Returns (CARs) of selected Asian stock markets during periods of Pre-COVID and COVID-19 under the event window $(0,10)$. According to Table 5, all selected countries except Hong Kong, Singapore, Korea, Thailand, and Vietnam have reported negative CARs during the COVID $(0,10)$ window compared to pre-COVID $(0,10)$ window. Despite Vietnam has reported a positive CAR (0.01971) during COVID-19, the CAR is lower than that of pre-COVID-19 (0.05752). It implies that actual stock returns of most Asian Stock Markets are lower than that of expected stock return during the COVID-19 period. This notion is more substantial in the countries such as Bangladesh, Sri Lanka and Indonesia where the CARs during COVID-19 were $-0.13462,-0.12188$ and -0.10184 respectively. Hence, it is apparent that COVID-19 has drastically affected the stock return of most Asian Stock Markets during $(0,10)$ event window.

The event window $(10,20)$ indicates the immediate impact of COVID-19 on stock returns after informing the global spread of COVID-19 on the $20^{\text {th }}$ of January 2020 . In addition to 
Oshini Kumarapperuma, Ravindra Deyshappriya and Rajapaksha

examination of immediate impact, the event window $(10,20)$ was also applied to check the further impact of COVID-19 on stock return even 10 days after the event day.

Table 5: Cumulative Abnormal Return in the Event Window $(0,10)$ with a Comparison of Pre-Event Window $(0,10)$

\begin{tabular}{lcc}
\hline \multicolumn{1}{c}{ Country } & \multicolumn{2}{c}{ Cumulative Abnormal Return } \\
\cline { 2 - 3 } & COVID $(0,10)$ & Pre-COVID $(0,10)$ \\
\hline Hong Kong & 0.02632 & -0.00855 \\
Japan & -0.00800 & 0.01378 \\
Singapore & 0.01307 & -0.00484 \\
China & -0.01937 & 0.02438 \\
India & -0.05537 & 0.01267 \\
Indonesia & -0.10184 & 0.10258 \\
Korea & 0.03214 & 0.02689 \\
Pakistan & -0.01816 & 0.05779 \\
Malaysia & -0.06335 & -0.00747 \\
Philippines & -0.00779 & 0.02455 \\
Taiwan & -0.05323 & -0.05119 \\
Thailand & 0.13020 & 0.01604 \\
Bangladesh & -0.13462 & 0.00982 \\
Sri Lanka & -0.12188 & 0.01528 \\
Vietnam & 0.01971 & 0.05752 \\
\hline
\end{tabular}

Source: Authors calculation based on collected data

Table 6 compares the Cumulative Abnormal Returns (CARs) of selected Asian stock markets during periods of Pre-COVID and COVID-19 under the event window (10, 20). As Table 6 indicates, only the stock markets in countries such as Hong Kong, Malaysia, and Taiwan that have reported positive stock return under COVID-19 bound to the event window (10, 20). However, the CARs of both Hong Kong and Malaysia are lower than that of pre-COVID period, indicating possible adverse impact on these two countries as well. Apart from Hong Kong, Malaysia, and Taiwan, the stock market of all other countries has reported negative CARs during the event window $(10,20)$.

Adverse impact on stock return is more apparent in Bangladesh (-0.13462), Indonesia ($0.05180)$ and Japan (-0.04725) and therefore it is confirmed that COVID-19 affects stock markets irrespective of their market statuses such as developed, emerging and frontier. According to both table 05 and table 06, it can be concluded that the impact of COVID19 on stock return in Asian Stock Markets is more adverse in the event window $(10,20)$ compared to the event window $(0,10)$. 
South Asian Journal of Business Insights

Table 6: Cumulative Abnormal Return in the Event Window $(10,20)$ with a Comparison of Pre-Event Window $(10,20)$

\begin{tabular}{lcc}
\hline \multirow{2}{*}{ Country } & \multicolumn{2}{c}{ Cumulative Abnormal Return } \\
\cline { 2 - 3 } & COVID (10, 20) & Pre-COVID (10, 20) \\
\hline Hong Kong & 0.00089 & 0.01768 \\
Japan & -0.04725 & -0.01658 \\
Singapore & -0.00010 & -0.00987 \\
China & -0.00930 & 0.00530 \\
India & -0.00800 & 0.00863 \\
Indonesia & -0.05180 & 0.01280 \\
Korea & -0.00370 & -0.02397 \\
Pakistan & -0.04496 & 0.00069 \\
Malaysia & 0.01599 & 0.01647 \\
Philippines & -0.01013 & -0.00114 \\
Taiwan & 0.05507 & 0.04072 \\
Thailand & -0.04237 & -0.03119 \\
Bangladesh & -0.13462 & 0.00982 \\
Sri Lanka & -0.03214 & -0.01044 \\
Vietnam & -0.02699 & 0.02891 \\
\hline
\end{tabular}

Source: Authors calculation based on collected data

\section{Analysing the Impact of Confirmed Cases on Stock Returns}

Aligned with objectives of the study, fixed effect panel data regression was empirically estimated to study the impact of confirmed COVID cases on stock returns of Asian Stock Markets. According to the analysis, Cross-section dimension include the 15 indices ( $\mathrm{i}=$ $1, \ldots . \mathrm{N})$ and Time dimensions include the 20 periods $(20$ periods: $t=(0, \ldots \ldots 19)$. Hence, 300 observations were considered for the analysis. AR was assigned as the dependent variables and independent variables have been gradually added and observed the robustness of the relationship between confirmed COVID cases and stock return.

According to Table 07, the log of confirmed cases negatively affects AR in all three models and estimated coefficients are statistically significant at $5 \%$ level. Therefore, it is confirmed that a higher number of confirmed COVID cases worsens the smooth running of the economy and hence stock markets are also affected. This relationship is more stable and robust as the estimated coefficient are statistically significant even after controlling for other independent variables and the finding aligns with Liu et al. (2020) as well. 
Oshini Kumarapperuma, Ravindra Deyshappriya and Rajapaksha

Table 7: Fixed Effect Panel Regression Results on Confirmed COVID Cases and Abnormal Return

\begin{tabular}{lccc}
\hline Variables & AR (Model 1) & AR (Model 2) & AR (Model 3) \\
\hline Log of & $-0.0086^{* *}$ & $-0.0036^{* *}$ & $-0.0024^{* *}$ \\
Confirmed & $(0.0043)$ & $(0.0017)$ & $(0.0011)$ \\
Return & & $0.7530^{* * *}$ & $0.6532^{* * *}$ \\
& & $(0.0321)$ & $(0.0561)$ \\
Exchange Rate & & & $0.0146^{*}$ \\
& & & $(0.0076)$ \\
Market & & & $0.0259^{* * *}$ \\
Capitalization & & & $(0.0031)$ \\
Constant & 0.0127 & 0.0012 & $0.0146^{*}$ \\
& $(0.0236)$ & $(0.0165)$ & $(0.0076)$ \\
Observation & 300 & 300 & 300 \\
R-Squared & 0.2034 & 0.5421 & 0.7843 \\
VIF & 1.2553 & 2.1838 & 4.636 \\
Time Control & Yes & Yes & Yes \\
Country Control & Yes & Yes & Yes \\
\hline
\end{tabular}

Source: Authors calculation based on collected data

Note: Robust standard errors in parentheses, ${ }^{* * *} p<0.01,{ }^{* *} p<0.05,{ }^{*} p<0.1$.

COVID-19 related lockdowns essentially collapsed the production networks and therefore lessen the profit of firms and ultimately all these adverse effects are reflected from stock prices and returns. Moreover, global uncertainty occurred due to COVID-19 drastically affect capital mobility across the countries and therefore stock markets started to collapse gradually. In addition to the key variable of confirmed COVID cases, all other variables such as stock return, exchange rate and market capitalization positively $A R$ and the relationships are statistically significant at $1 \%, 10 \%$ and $1 \%$ respectively. Higher coefficient of determination (0.7843) in the model 4 emphasizes the goodness of fit of the model while higher Variance Inflation Factors (VIFs) which are more than one in all three models confirm that the models are free from multicollinearity issue.

\section{Conclusions and Recommendations}

The consequences of a pandemic on the global economy have been apparent throughout history. COVID-19 emerged from China and rapidly outbreak across the globe, and hence the World Health Organization had announced a global emergency situation as well. Stock markets play a vital role in both individual and global economic contexts and however, the stock markets are highly sensitive to any kind of shocks. Hence, this study attempts to examine the impact of COVID-19 on the stock market of 15 Asian countries which represent developed, emerging, and frontier markets. Specifically, the study focuses on 
South Asian Journal of Business Insights

the impact of COVID-19 on stock returns of selected markets while observing the relationship between confirmed COVID-19 cases and stock return. The impact of COVID19 on stock returns was analysed using the Event Study method. $20^{\text {th }}$ of January, 2020 was considered as the event day as international media announced the wide spread of COVID-19 on $20^{\text {th }}$ of January, 2020. Based on this event day, two evet windows such as $(0,10)$ and $(10,20)$ were assigned to compare the calculated abnormal return before and after the event day. Abnormal returns were calculated by subtracting actual returns from expected turns based on OLS regression analysis. Apart from that, fixed effect panel regression analysis was carried out to observe the impact of the number of COVID-19 confirmed cases on stock return in selected stock markets. Daily closing price indices during the period of 1st January 2019 and 30th June 2020 were used to calculate the abnormal return and the empirical results of the event study reveal that abnormal returns after the event day are negative and therefore it is apparent that the COVID-19 outbreak has drastically affected the stock returns of selected stock markets of the Asian region. Specifically, two event windows indicate that COVID-19 has an immediate negative impact on all selected stock markets while long-term negative impact has limited to emerging and frontier markets. Moreover, it is observed that COVID-19 confirmed cases negatively affect the stock return of all selected stock markets in the Asian region. Hence, the current study recommends the importance of recovering from the pandemic and sustaining an appropriate environment for the development and smooth running of stock markets.

\section{References}

Agrawal, J., \& Kamakura, W. A. (1995). The economic worth of celebrity endorsers: An event study analysis. Journal of Marketing, 59(3), 56-62. https://doi.org/10.1177/002224299505900305

Al-Awadhi, A. M., Alsaifi, K., Al-Awadhi, A., \& Alhammadi, S. (2020). Death and contagious infectious diseases: Impact of the COVID-19 virus on stock market returns. Journal of Behavioral and Experimental Finance, 27, 100326. https://doi.org/10.1016/j.jbef.2020.100326

Ali1, R., \& Afzal, and M. (2014). Impact of global financial crisis on stock market volatility: Evidence from Pakistan and India. Asian Social Science, 1010), 86-94. https://doi.org/10.5539/ass.v10n10p86

Asian Development Bank. (2020). The economic Impact of the COVID-19 outbreak on developing Asia. 9(128). https://doi.org/10.22617/BRF200096

Baker, M., Wurgler, J., \& Yuan, Y. (2012). Global, local, and contagious investor sentiment. Journal of Financial Economics, 104(2), 272-287. https://doi.org/10.24149/gwp37

Ball, R., \& Brown, P. (1968). An empirical of accounting income numbers. Journal of Accounting Research, 159-178.

Barnett, T., Whiteside, A., Khodakevich, L., Kruglov, Y., \& Steshenko, V. (2000). The HIV/AIDS epidemic in Ukraine: its potential social and economic impact. Social Science \& Médicine, 51(9), 1387-1403. 
Oshini Kumarapperuma, Ravindra Deyshappriya and Rajapaksha

Bianconi, M., Yoshino, J. A., \& De Sousa, M. O. M. (2013). BRIC and the U.S. financial crisis: An empirical investigation of stock and bond markets. Emerging Markets Review, 14, 76-109. https://doi.org/10.1016/j.ememar.2012.11.002

Bloom, D. E., \& Mahal, A. S. (1997). Does the AIDS epidemic threaten economic growth? Journal of Econometrics, 77(1), 105-124. https://doi.org/10.1016/S03044076(96)01808-8

Carpenter, T. E., O'Brien, J. M., Hagerman, A. D., \& Mccarl, B. A. (2011). Epidemic and economic impacts of delayed detection of foot-and-mouth disease: A case study of a simulated outbreak in California. Journal of Veterinary Diagnostic Investigation, 23(1), 26-33. https://doi.org/10.1177/104063871102300104

Chen, M. H., Jang, S. S., \& Kim, W. G. (2007). The impact of the SARS outbreak on Taiwanese hotel stock performance: An event-study approach. International Journal of Hospitality Management, 26(1), 200-212.

https://doi.org/10.1016/j.ijhm.2005.11.004

Chene, G., Cerruto, E., \& Nohuz, E. (2018). The effect of the SARS epidemic on China's long-term relationship with four Asian stock markets. International Urogynecology Journal, 6-7. https://doi.org/10.1007/s00192-020-04463-6

Chia, R. C. J., Liew, V. K. S., \& Rowland, R. (2020). Daily new Covid-19 cases, the movement control order, and Malaysian stock market returns. International Journal of Business and Society, 21(2), 553-568

Delisle, J. (2003). SARS, greater China, and the pathologies of globalization and transition. Orbis, 47(4), 587. https://doi.org/10.1016/S0030-4387(03)00076-0

Dolley, J. C. (1933). Open market buying as a stimulant for the bond market. Journal of Political Economy, 41(4), 513-529.

Erdem, O. (2020). Freedom and stock market performance during Covid-19 outbreak. Finance Research Letters, 36, 101671. https://doi.org/10.1016/j.frl.2020.101671

Forbes, K., \& Rigobon, R. (2001). Measuring contagion: conceptual and empirical issues. In International financial contagion (pp. 43-66). Springer, Boston, MA.

Gaver, J. J., Gaver, K. M., \& Battistel, G. P. (1992). The stock market reaction to performance plan adoptions. Accounting Review, 67(1), 172-182.

James, L., Shindo, N., Cutter, J., Ma, S., \& Chew, S. K. (2006). Public health measures implemented during the SARS outbreak in Singapore, 2003. Public Health, 1201), 20-26. https://doi.org/10.1016/j.puhe.2005.10.005

Jin, Z., Du, X., Xu, Y., Deng, Y., Liu, M., Zhao, Y., Zhang, B., Li, X., Zhang, L., Peng, C., Duan, Y., Yu, J., Wang, L., Yang, K., Liu, F., Jiang, R., Yang, X., You, T., Liu, X., ... Yang, H. (2020). Structure of Mpro from SARS-CoV-2 and discovery of its inhibitors. Nature, 582(7811), 289-293. https://doi.org/10.1038/s41586-020-2223-y

Lee, J. W., \& McKibbin, W. J. (2004). Globalization and disease: The case of SARS. Asian Economic Papers, 3(1), 113-131.

Lee, K. Y. M., Jais, M., \& Chan, C. W. (2020). Impact of covid-19: evidence from Malaysian stock market. International Journal of Business and Society, 21(2), 607-628. 
South Asian Journal of Business Insights

Liu, H., Manzoor, A., Wang, C., Zhang, L., \& Manzoor, Z. (2020). The COVID-19 outbreak and affected countries stock markets response. International Journal of Environmental Research and Public Health, 17(8), 1-19.

https://doi.org/10.3390/ijerph17082800

Mazur, M., Dang, M., \& Vega, M. (2021). COVID-19 and the march 2020 stock market crash. Evidence from S\&P1500. Finance Research Letters, 38, https://doi.org/10.1016/j.frl.2020.101690

McKibbin, Warwick J. and Fernando, Roshen, Global Macroeconomic Scenarios of the COVID-19 Pandemic (June 25, 2020). CAMA Working Paper No. 62/2020, Available at SSRN: https://ssrn.com/abstract=3635103 or http://dx.doi.org/10.2139/ssrn.3635103

Nikkinen, J., Saleem, K., \& Martikainen, M. (2013). Transmission Of The Subprime Crisis : 29(5), 1469-1479.

Okorie, D. I., \& Lin, B. (2021). Stock markets and the COVID-19 fractal contagion effects. Finance Research Letters, 38, 101640. https://doi.org/10.1016/j.frl.2020.101640

Raga, S. (2020). Economic vulnerabilities to the coronavirus: top countries at risk. ODI's

Reena Aggarwal \& Carla Inclan, R. L. (1999). Volatility in Emerging Stock Markets Reena Aggarwal, Carla Inclan, and Ricardo Leal *. Journal of Financial and Quantitative Analysis, 34, 33-55.

Ru, H., Yang, E., \& Zou, K. (2020). What Do We Learn from SARS-CoV-1 to SARS-CoV-2: Evidence from Global Stock Markets. SSRN Electronic Journal, 639798. https://doi.org/10.2139/ssrn.3569330

Siu, A., \& Wong, Y. R. (2004). Economic impact of SARS: The case of Hong Kong. Asian Economic Papers, 3(1), 62-83.

Thompson, A. J. (1993). The Anticipated Sectoral Adjustment to the Canada - United States Free Trade Agreement: An Event Study Analysis. The Canadian Journal of Economics, 26(2), 253. https://doi.org/10.2307/135906

Topcu, M., \& Gulal, O. S. (2020). The impact of COVID-19 on emerging stock markets. Finance Research Letters, 36, 101691. https://doi.org/10.1016/j.frl.2020.101691

Vijayakumar, K., George, B., Anish, T. S., Rajasi, R. S., Teena, M. J., \& Sujina, C. M. (2013). Economic impact of chikungunya epidemic: Out-of-pocket health expenditures during the 2007 outbreak in Kerala, India. Southeast Asian Journal of Tropical Medicine and Public Health, 44(1), 54-61.

Wang, Y. H., Yang, F. J., \& Chen, L. J. (2013). An investor's perspective on infectious diseases and their influence on market behavior. Journal of Business Economics and Management, 14(SUPPL1), 112-127. https://doi.org/10.3846/16111699.2012.711360

Zhang, D., Hu, M., \& Ji, Q. (2020). Financial markets under the global pandemic of COVID19. Finance Research Letters, 36. https://doi.org/10.1016/j.frl.2020.101528 
Annex 1: Most Active Companies in Selected Markets

\begin{tabular}{|c|c|}
\hline Country & Company \\
\hline \multirow[t]{3}{*}{ Hong Kong } & Bank of China Ltd H \\
\hline & Sino Biopharmaceutical Ltd \\
\hline & Petro China Co Ltd Class $\mathrm{H}$ \\
\hline \multirow[t]{3}{*}{ Japan } & Mizuho Financial Group Inc \\
\hline & Mitsubishi UFJ FinancialGroup Inc \\
\hline & Softbank Group Crop \\
\hline \multirow[t]{3}{*}{ Singapore } & Keppel Corporation Limited \\
\hline & HongKong Land Holding Limited \\
\hline & Jardine Cycle \& Carriage Ltd \\
\hline \multirow[t]{3}{*}{ China } & Inner Mongolia Junzheng Energy \& Chemical Group Co Ltd \\
\hline & Pacific Securities Co Ltd \\
\hline & China Shipbuilding Industry Co Ltd \\
\hline \multirow[t]{3}{*}{ India } & State Bank of India \\
\hline & ITC Bank \\
\hline & Reliance Industries Ltd \\
\hline \multirow[t]{3}{*}{ Indonesia } & PP Properti Tbk PT \\
\hline & HK Metals Utama Tbk PT \\
\hline & J Resources Asia Pacific Tbk \\
\hline \multirow[t]{3}{*}{ Korea } & Sy Material \\
\hline & Samsung Pharm \\
\hline & Taihan Electric Wire Co Ltd \\
\hline \multirow[t]{3}{*}{ Malaysia } & Top Glove Corporation Bhd \\
\hline & Genting Malaysia Bhd \\
\hline & Hartalega Holdings Bhd \\
\hline \multirow[t]{3}{*}{ Pakistan } & Unity Foods Ltd \\
\hline & K-Electric Ltd \\
\hline & Fauji Fertilizer Bin Qasim Ltd \\
\hline \multirow[t]{3}{*}{ Philippines } & SM Prime Holdings Inc \\
\hline & Metro Pacific Inv \\
\hline & Megaworld Corp \\
\hline \multirow[t]{3}{*}{ Taiwan } & United Microelectronics Corporation \\
\hline & AU Optronics \\
\hline & Innolux Corp \\
\hline Thailand & Superblock PCL \\
\hline
\end{tabular}


South Asian Journal of Business Insights

\begin{tabular}{ll}
\hline \hline \multirow{3}{*}{ Bangladesh } & Absolute Clean Energy Public Co Ltd \\
& TMB Bank PCL \\
& National Bank Ltd \\
& Beximco Pharmaceuticals Ltd \\
& Orion Pharma Ltd \\
Sri Lanka & Browns Investments PLC \\
& Colombo Fort Land \& Building PLC \\
& Industrial Asphalts (Ceylon) PLC \\
Vietnam & HUD-TASCO \\
& SHS \\
& Petroleum Technical Services
\end{tabular}

Source: Created by Authors Based on Inveting.com Website

\section{Author Biography}

Oshini Kumarapperuma is an undergraduate of the Faculty of Management of Uva Wellassa University of Sri Lanka.

N.P. Ravindra Deyshappriya is a Senior Lecturer of Faculty of Management and the Director of Centre for Open \& Distance Learning of Uva Wellassa University of Sri Lanka.

R.M.M.C. Rajapaksha is a former Lecturer of the Faculty of Management of Uva Wellassa University of Sri Lanka. 